\title{
A practical-theological reflection on the usage of symbols and metaphors in intercultural pastoral care in South Africa
}

Author:
Amanda Du Plessis ${ }^{1}$
Affiliation:
'Department of Theology,
Faculty of Human and Social
Sciences, Mafikeng campus,
Northwest-University
Corresponding author:
Amanda du Plessis,
amanda.duplessis@nwu.
ac.za
Dates:
Received: 31 May 2016
Accepted: 31 Oct. 2016
Published: 05 Dec. 2016
mobile device
to read online.
How to cite this article:
Du Plessis, A., 2016, 'A
practical-theological
reflection on the usage of
symbols and metaphors in
intercultural pastoral care in
South Africa', HTS Teologiese
Studies/Theological Studies
72(2), a3517. http://dx.doi.
org/10.4102/hts.v72i2.3517
Copyright:
@ 2016. The Authors.
Licensee: AOSIS. This work
is licensed under the
Creative Commons
Attribution License.

\begin{abstract}
The African continent is associated with a variety of problems. Irrespective of having achieved a new democracy more than two decades ago, South Africa still seems to suffer the same fate as the rest of the continent because of the inability to solve its innate challenges. However, at grass roots level South Africans are desperately seeking ways of moving away from this problem-focused paradigm to a more constructive and assertive paradigm where South Africans can truly be reconciled as a 'rainbow nation' despite the different cultures. Scholars who have written about this intercultural challenge are of the opinion that intercultural hermeneutics no longer works with a split between Christ and culture, but rather with the interconnectedness between Christ and culture, without the sacrifice of the culture's uniqueness. One cannot understand religion, faith and spirituality without understanding culture. This article investigates the church's responsibility to provide pastoral care to the people of South Africa within an intercultural paradigm by using different symbols and metaphors. The research question concentrates on the interconnectedness of the Christian faith and the different cultures in South Africa. It examines how a pastoral approach, using symbols and metaphors, could contribute to the avoidance of the mere 'Christianisation' of the culture, resulting in an approach where Christ is the authentic transformer of culture.
\end{abstract}

\section{Introductory remarks}

The African continent is associated with a variety of problems. Irrespective of having achieved a new democracy more than two decades ago, South Africa still seems to suffer the same fate as the rest of the continent because of an inability to solve its innate challenges. However, at grass roots level, South Africans are desperately seeking ways of moving away from this problemfocused paradigm to a more constructive and assertive paradigm where South Africans can truly be reconciled as a 'rainbow nation', despite the different cultures. The cultural diversity in South Africa confronts the church and the pastoral care ministry with new challenges. Scholars such as Louw (2008:153), who have written about the intercultural challenge, are of the opinion that in intercultural hermeneutics we can no longer work with a split between Christ and culture. We should move to an interconnectedness between Christ and culture, without the sacrifice of a culture's uniqueness. One cannot understand religion, faith and spirituality without understanding culture. The importance of constructing contextual-theological models that inform the pastoral ministry can therefore not be overemphasised. In this regard, Bate (2012:69) states that theological (or pastoral) models 'need to bring together disciplined analysis of the context, a faithfulness to the Christian tradition, and innovation in developing contextual theological categories to inform ministry'.

\section{Epistemology and research method}

This article follows from a practical theology epistemology, more specifically its pastoral component. According to Osmer (2008:4), the following definition describes practical theology best: "The task of practical theology is to reflect critically on current practices in light of the Scriptures in order to promote growth in the praxis of the faith community.' Therefore, this article investigates the church's responsibility to provide pastoral ministry to the people of South Africa within an intercultural paradigm by using different symbols and metaphors. This epistemological point of departure is also the basis of what pastoral ministry entails. Louw (2010:73) formulates it as 'the expression and representation of the sensitivity and compassion of the Scriptures' understanding and portrayal of God's encounter, intervention, interaction and involvement in our human being'. Therefore, the research question concentrates on the interconnectedness of the Christian faith and the different cultures in South Africa. How can a pastoral approach using

Note: This article is published in the section Practical Theology of the Society for Practical Theology in South Africa. 
symbols and metaphors contribute by avoiding the mere 'Christianisation' of the culture, resulting in an approach where Christ is the authentic transformer of culture? In order to answer this, I subscribe to Bate's statement as mentioned in the introduction. I further explore the suggested themes that can contribute to pastoral ministry guidance as they relate to the challenge of integrating the people of South Africa. In doing this, the article unfolds as follows:

- culture, world view and religion in the present South Africa

- understanding the symbolic process and the use of symbols and metaphor in pastoral ministry

- contextual theological thoughts on the use of symbols and metaphors in pastoral ministry.

\section{Culture, world view and religion in the present South Africa}

Firstly, the following diagram simplifies the complex interaction between the people of South Africa and the difficult issues we are facing. It is important to note that a diagram is always an oversimplification and researchers should use it with great caution. For the sake of simplicity, the diagram only includes the three components under discussion in this article, namely religion (Christian faith), Western culture and African traditional culture. Of course, each of these components has various layers. The purpose of Figure 1 is to offer a point of departure from which to consider the theme of the article.

Before discussing the diagram, it is important to acknowledge the limitations of the diagram and to do a literary overview of the concepts under discussion.

Firstly, South Africa is a multi-cultural country and has many more cultures than indicated in the diagram. For the

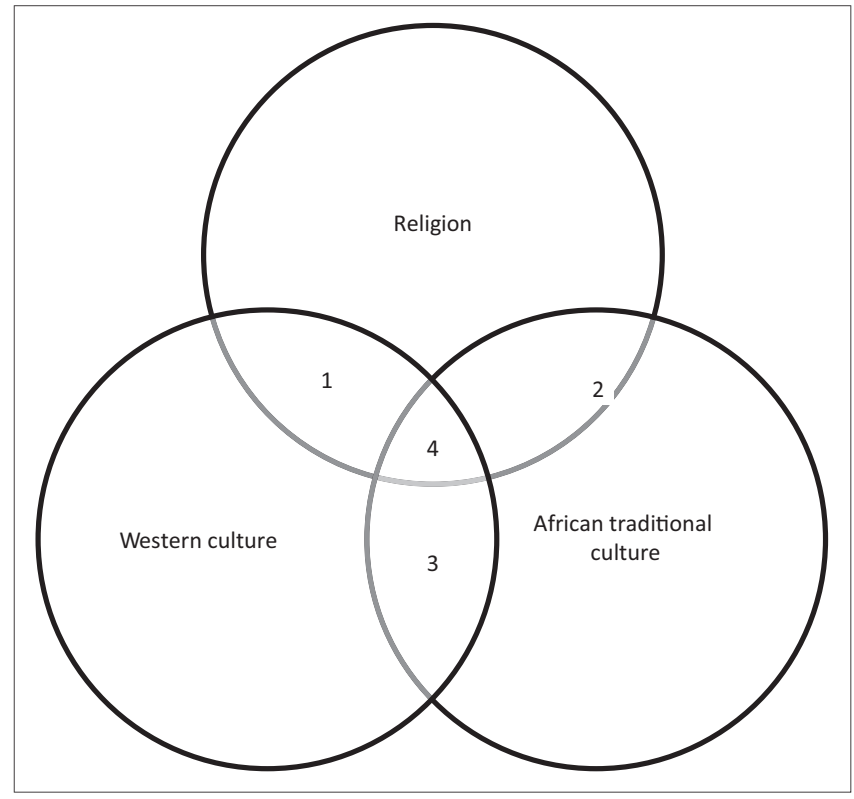

Source: Diagram developed by author

Figure 1: Departure point for theme of article. sake of simplicity, the diagram divides cultures into two groups, Western culture and African traditional culture. Secondly, there are a variety of religions in South Africa. This article only discusses the Christian faith. Thirdly, although the diagram distinguishes between religion and culture, these two are interwoven and inseparable from each other. Culture is coloured by religion, and vice versa.

The available literature reveals the following number of points relevant to the study. According to Van der Walt (2003:93), culture is the human's 'frame of reference' for understanding and behaviour. Therefore, the human also has the task of answering to the real God according to a specific world view that describes his or her place in the world. Louw (2008:151) defines culture as a way of life for a given period of time or a place. It is replete with specific values, symbols and inherent meaning. Humans are embedded in culture, and can therefore not be understood separate from cultural issues and values. The Latin word colo means to nurse, take care of, or to transform the earth through work in order to live. Culture is the human endeavour of cultivating creation so that it becomes a human space for living, including life with certain symbols, metaphors, language and instruments (Louw 2008:153). A world view functions like a map, it provides orientation; like a compass, it gives direction from a deep religious commitment and calls for action. It not only helps us to understand reality better, but to deal with it correctly (Van der Walt 2003:101). The Western world view believes in the individual autonomy of man and the African world view in communal autonomy. One can define religion as the central directedness of all human life towards the real or presumed ultimate source (God or gods) of meaning and authority (Van der Walt 2003:101).

Niebuhr's work, Christ and culture (1952), on the relationship between the Christian faith and culture has become a classic in the academic world. He describes various models to depict this relationship:

- The rejection and anti-model: In this approach Christ is portrayed as against culture (pp. 45-81).

- The accommodation model: In this approach Christ is portrayed as the Christ of culture (pp. 83-103).

- The synthesis model: Christ is portrayed as above culture, that is to maintain the distinction between Christ and culture (pp. 117-148).

- The dualistic model: Christ and culture are portrayed in a paradoxical relationship (pp. 149-189).

- The operational model: Christ is the transformer of culture. Niebuhr believes that although Christ is above culture he operates through it to transform (convert) it (pp. 191-210).

Van der Walt (2003:102) indicates very strongly that the biblical message is clear: 'The Gospel associated itself with different cultures - never to be domesticated, nor to be the captive of these cultures, but to liberate and transform them.' 
Taking all the above into consideration, the discussion of the diagram unfolds as follows:

\section{Overlap between religion and Western culture}

Many Christians read the Bible through the spectacles of their world view, because they cannot rid themselves of the culture within which they have been educated and the convictions to which they adhere. This is not a new phenomenon. Dualistic world views have been part of the history of Christianity from the time when the gospel was no longer restricted for use by the Jews only. Very frequently, believers either adjust to an attitude of conformity to the world, or flee from it (Van der Walt 2003:515-516). This dualistic view continued until the time of the Reformation, at which time thinkers like Calvin and Luther stated that culture and religion had to be concretely and fully involved in the world to transform and renew it. Sadly, during the post-Reformation and Protestant eras, theologians fell back into the dualistic view and an everincreasing reliance on reason replaced the living faith of the reformers (Van der Walt 2003:520). After a period during which people viewed Christianity as cold, lifeless and negative, Abraham Kuyper and Herman Bavinck were able to revive the reformational idea (Van der Walt 2003:520). From then onwards there has been a long list of reformational theologians. Unfortunately, the dualistic view is still very much alive in many churches, resulting in a religion that is more Western than Christian. The mere Christianisation of culture has led to an emphasis on the individual. This focus on the individual reduces the Christian faith to a 'feel-good' religion, instead of a call to live according to the kingdom principles. In many situations, hermeneutics is based on eisegesis, instead of good unblemished exegesis. In light of this, we can understand why the Afrikaans churches in South Africa initially approved apartheid and the white domination over black people. At the end of the apartheid era, many of these churches made statements repenting the rationalisation of apartheid. The Belhar Confession is an important document in this regard. Mere Christianisation of culture adheres to the dualistic model such as the one where Niebuhr (1952:149) describes Christ and culture to be in a paradoxical relationship. The inability to understand Christ as the actual transformer of culture is evident. Kretzschmar (1986) demonstrates something of what happened between religion and Western culture as (a) opposed to the overlapping between religion and the African traditional culture (b), and by quoting Albert Luthuli (in Kretzschmar 1986):

White paternalist Christianity ${ }^{1}$ - as though whites have invented the Christian faith - estranged my people from Christ. Hypocrisy, double standards, and the identification of white skins with Christianity, do the same. (p. 10)

He (in Kretzschmar 1986:25) continues to say that the gospel, as the 'mission churches' preached it, is irrelevant to the experience and questions of Africans in some of its emphases. As a result, Christianity was not able to touch, renew or become part of the inner core of the experience of a large group of believers.

2. Overlap between religion and African traditional culture African theologians today object to how Christianity (presented as part of Western culture) has been used to deny the value of African culture and its world view. Tutu (1971) acknowledges that the Africans cannot simply place the blame on white shoulders, because:

$[W]$ e African theologians are quite as much to blame as anyone else, for we find it much easier to regurgitate what was fed into us, than to use our acquired skills for creative theological thinking. (p. 111)

According to Kretzschmar (1986:27), awareness of God and to a lesser extent direct worship of God, was an important feature of African life prior to the work of the missionaries. Within African life, religion is not a separate facet, but closely interrelated with many conceptions and practices. Therefore, a single uniform God image does not exist in the diverse African spirituality (Louw 2008:161). Rather, Africans perceive divinity in terms of a force ${ }^{2}$ that moves and rules humanity and determines their fate in the world. Africans view no less than four different groups of spirits as real entities that are involved in the life events of an African. Louw (2008:165) describes the spirits as (1) divinities that are manifestations of God, (2) ancestral spirits, who are the protectors of life and community, (3) life spirits, who are involved in rituals as part of animistic practices and part of nature and natural events, and (4) evil spirits, who are influential in life events. In Western culture, the aspect of ancestral spirits is unknown. There is no consensus within the different South African tribes as to how they view ancestral spirits. The Zulu and Basotho people regard the ancestors as creatures and not gods, therefore they speak to, rather than pray to the ancestors. The idea of ancestral veneration is similar to the Christian concept of the Communion of Saints (Kretzschmar 1986:31). In contrast, the Xhosa-speaking Christians still practise, often privately, ancestor veneration, even though the Western churches tend to reject this emphasis as idolatry. For this reason, Bosch (1973:12) speaks of the need for continuity and discontinuity with respect to belief in God. He shows how, in relation to the Canaanite god Baal, or the Greek unknown god, the God of the Bible adapts some views and replaces others in the process of his self-revelation. Kretzschmar (1986:29) indicates that this continuity and discontinuity will result in African concepts of God being both transformed and effectively incorporated, dependent on their value and truth.

This very short description of the overlap between religion and African traditional culture also indicates the tendency of the mere Christianisation of culture and its resemblance to the accommodation model (Niebuhr 1952:83). It portrays God as the God of culture, despite man's inability to 2.The Sotho-Tswana word 'Modimo' means penetrating force. 
understand Christ as the actual transformer of culture. This results in conflict about whose religion the true gospel is and shows the absence of true integration. The question is whether the people of South Africa are not all guilty of adapting the message of the gospel in such a way that it becomes comfortable within their own culture, rather than a challenging or transforming fire within their particular culture.

3. Overlap between Western and African traditional culture This overlap creates a multiculturality, in other words the reality of different cultures within a system of active interaction. The section indicates a life according to a culture, world view and philosophy in which the Word of God is not authoritative. Van der Walt (2003:98) labels the inhabitants as 'divided souls' or people with an 'identification conflict' resulting from the contact between different cultures. In a certain sense, this is a common phenomenon in South Africa because of the clash between traditional African and modern Western culture. For example, black people leave rural areas and adopt a Western lifestyle in the cities, but still participate in different rituals when returning to the rural setting. In the political, economic and socio-ethical field, these clashes sometimes play out in different forms, for example racism, sexism, xenophobia, et cetera. Eventually, all cultures change, some slowly, others more rapidly. They do so by way of inter alia the following: (1) inheritance, (2) innovation, (3) the free borrowing or adoption from other cultures and (4) forced change due to a foreign, imposed culture (Van der Walt 2003:97).

4. Integration of all three components of the diagram

With reference to the diagram, true integration of all three components (d) depends on an intercultural paradigm that links with the operational model (Niebuhr 1952:191) where Christ is the transformer of culture. A mutual listening to and a mutual understanding of the different cultures, together with an attitude of living the commandment of love and kingdom principles, are the prerequisites for true integration. Real change in any culture is stimulated from its core, in other words religion and a world view. Kretzschmar (1986:26) states that in true integration the emphasis must be on 'holistic salvation, and not salvation that affects only the soul or spiritual things, but one that touches, heals and changes all of life.' This follows from a viewpoint that the Christian faith is the essence of life. It is not a separate, spiritual component, but an attitude that penetrates all parts of one's life as a whole. It also determines how the believer should view the interrelatedness between humans of different cultures. Louw (2008:154) states that to be fully human is to be connected to life, and that this connectedness further implies mutual interconnectedness, because life is about the principle of interrelatedness and communality. This statement reminds one of the 'ubuntu call' echoing throughout the African world view and therefore also throughout South Africa. Ubuntu is about the enrichment of one's own humanity by that of another. This challenge brings us to the second part of the article. This part examines how pastoral ministry that uses symbols and metaphors could contribute to true integration where Christ is the authentic transformer of culture. The discussion starts with a look at the symbolic process.

\section{Understanding the symbolic process and the use of symbols and metaphors in pastoral ministry}

Although pastors practise pastoral ministry with great care, there is often a disjunction in the communication when the experience of the pastor does not match the cultural paradigm of the other person. Therefore, intercultural hermeneutics takes on the challenge of bridging the gap to understand the symbolic meanings of other cultures and faith systems, because symbols and metaphors are, according to Prattis (2001), multilevelled and polyvalent, as:

[T] hey connect to other symbols (and metaphors) in ways that are often unrecognized. It takes human experience and understanding of symbols to open doorways to yet deeper understanding of that same symbol. Thus a symbol - e.g. the cross - can have meaning at different levels for different people, but can also change meanings as individuals engage more deeply with that symbol in an ongoing phenomenological relationship. (p. 38)

Prattis (2001:39) refers to symbols and metaphors as 'communication vehicles' that operate as pointers to the unknown. Therefore, symbols and metaphors help us organise and interpret the situation. They give meaning and a certain structure to our understanding (Coll 1985:374). A symbol consists mainly of three parts: the symbol itself, the object it represents and our understanding or interpretation thereof. On the other hand, a metaphor can be defined as playing with language in our understanding or interpretation of a symbol. A figure of speech for instance uses the familiar to speak in a striking, often shocking way about the unfamiliar. The pastoral ministry is primarily concerned with 'the whole linguistic process by which the truth is carried over (metaphora)' (Lane 1987:487).

In his research on the way Jesus used metaphors during his earthly ministry, Lane (1987:488-502) distinguishes four characteristics. In the first instance, he emphasises that metaphors had an open-ended quality that unnerved as much as they annoyed the imagination of the listeners, while forcing the listeners to make new connections of meaning and subsequently to adopt new ways of acting. This demanded involvement from listeners. Secondly, he points out that Jesus often used language against language, which means that the listeners were provoked into action more by what did not fit their expectations, than by what did. This language confusion forced the listeners to look for unanticipated meanings. One example of this language confusion is when Jesus refers to a 'good Samaritan' while speaking to Jews. It is as contradictory as referring to a 'good terrorist [sic]' (Lane 1987:493). The third characteristic refers 
to a 'metaphorical indirection', where a substitution occurs in the minds of the listeners. For example, when Nathan had to confront David about his sin in 2 Samuel verse 12, the prophet made use of this kind of metaphor. The narrator tells the listeners a 'safe' story so that they can consciously relate to the situation of the other, yet there is also an unconscious transference of meaning. Lastly, Lane (1987:499) reflects on the innate humility in metaphors. He quotes Barth who says that doing theology is like trying to paint a bird in flight. It is just too amazing to fully comprehend and pin down. Each effort is only a partly adequate attempt to know God. As a result, certain metaphors dominate pastoral ministry, for example the shepherd and prophet metaphors. The power of metaphors is that it stretches the imagination of the listeners in a desperate search for meaningful connections, reaching beyond the limits of language to where growth can occur.

With the above definition of symbols and metaphors in mind, I now reflect on research on the current usage of symbols and metaphors in pastoral ministry. Mpolo (1985:314) writes that during her ministry she became aware that the African world view consists of proverbs, myths, gestures and rites, which missionary and colonial powers condemned, but which are of significant importance for pastoral ministry. These symbols and metaphors convey messages that reveal ways in which African people organise their human relationships and social aspects, such as marriage, healing, birth, death, et cetera. Mpolo (1985) voices the result of the condemnation of these activities as follows:

$[O]$ ne learns that many communal activities of many Christians in Africa take place outside the Church. Many such rituals are viewed by the Christian Church as pagan. Most Christians, on the other hand, see the Church as a foreign institution, intruding upon, but not integrated with their social institutions which do respond to their deeper pastoral needs. (p. 314)

Although this quote dates from nearly three decades ago, it is still relevant today, for one cannot study and develop pastoral ministry in Africa outside the emerging African theology in an attempt to interpret the biblical message for African peoples. The pastoral ministry of the church should therefore take into consideration the paradoxes in African identity resulting from cultural ambiguities and the history of oppression (Mpolo 1985:322).

It is important to remember that Christianity has a different shape in each culture. Christianity was born in the Jewish culture and then spread to the Greek and Roman cultures. Centuries later, Christianity left Europe and later North America for Africa, resulting in two cultures coming together when the gospel arrived in Africa: the European (Western) culture and the indigenous African culture (Oduro et al. 2008:19). In his book Postcolonializing God, Lartey (2013) reflects on making the current discourse of practical theology relevant to an African practical theology. He (2013:4) states that the starting point for pastoral ministry must always be the exigencies of the people's experiences of life, especially helping them with their suffering, losses and tragedies. In order to answer to this challenge, there should be a paradigm shift from globalisation and internationalisation to indigenisation. Lartey (2013:118) defines globalisation as a comprehensive pastoral ministry based on Western research and methodology, and internationalisation as an effort to work cross-culturally. However, he states that the huge gap between the Western and African methodology only adds to its deficiency. Indigenisation is seen as the counterbalance for Western predispositions and in this sense, pastoral ministry becomes a double-edged sword with the cutting surfaces of community building on the one side, and culture transformation on the other. The handle of the sword is the incorporation of spirituality.

Lartey (2013:26) identifies seven pervasive characteristics that are discernible in African traditional religions. I want to reflect on only two characteristics that are relevant to the theme of this article. Firstly, Lartey (2013:28) points out that African theology is not so much a matter of beliefs, dogmas and creeds, as it is a performance of powerful ritual symbols and the expression of communal solidarity through participation in the rituals. Secondly, African religion is demonstrably flexible, pliable, pluralistic and adoptable, and it has reinvented rituals or symbols in different ways and forms. He (2013:29) states that wherever Africans go, they form communities of faith and ritual practices in an effort to bring healing and stability. Different types of rituals and symbols for instance include the playing of drums, symbolic actions, sacrifices, prayers, washing of hands or feet, music, dance, praise or physical movement. Lartey (2013:119) emphasises the centrality of spirituality in the use of symbols and metaphors and calls on pastoral care workers to engage the spiritual element, where spirituality instead of psychology becomes the major cognate discipline for pastoral ministry. He defines spirituality as a synthetic concept, which includes divine, psychological, social and ecological dimensions.

To my mind then, the biggest challenge for contextualising pastoral ministry in South African churches is to understand and overcome the prejudices regarding different cultural spiritualties. Pastoral workers should understand that spirituality aims to lead believers in a spiritually led life before God and to experience a deeper life with him. Syncretism becomes the practice when spirituality is not properly understood (Vilanculo 2009:236). The aim is to work towards an integration of the people of different cultures in South Africa and allowing Christ to be the transformer of culture. The call on the pastoral ministry is therefore to help persons fulfil their life's purpose and to discern and utilise their spirituality to navigate life's issues using the core beliefs of the gospel in such a way that these will contribute to the well-being of the community. There is evidently a need for a symbolic space to give voice to that which is beyond mere words. Therefore, the pastoral ministry should make use of symbols and metaphors capable of enabling the people of South Africa to express those inner feelings that they cannot always easily verbalise. Loving and listening, sharing and cultivating a sensitive understanding of cultural differences are essential to true integration. 


\section{Contextual theological thoughts on using symbols and metaphors in pastoral ministry}

The church has to operate from the point of departure that people should be approached from the perspective of their basic relationship with God and the 'roots of the church's pastoral ministry can be traced back to its age-old attempts at caring for the human soul' (Louw 2000:20). When linking this to Lartey's definition (2013:119), it implies a ministry not directed merely at the inner life, but at the care of the total person encompassing all the dimensions of life. The basis of this is the fact that 'soul' signifies the centre of human life as it is directed at God and as it manifests itself in relationships.

When looking at the development of pastoral care ministry, it is clear that it has developed into a scientific study and a branch of theology over the last century. Pastoral ministry has been linked to the shepherd and flock metaphors from early on as expressions of God's love and care for human beings in need, it deals with healing, guiding, sustaining and reconciling. Louw (2000:25) mentions that because of the pressures of modernity and post-modernity, the option to view pastoral ministry as an encounter between God and human beings with the focus on the communication of the gospel is no longer sustainable. The development of psychology and sociology put pressure on the agenda of the pastoral ministry. The result is that two very important resources of knowledge compete with one another: the gospel and the phenomenological world of contextual experience.

The core problem that pastoral ministry faces is to develop an interdisciplinary approach without losing its unique contribution to therapy: 'the healing dimension of salvation' (Louw 2000:25). This has resulted in the development of different pastoral models. The reformed model with the focus on the kerygma of salvation and forgiveness (Firet 1980; Heitink 1999) is one such model. Another is the client-centred or empirical model with the shift away from mainly a biblical focus to a more psychological point of departure (Tillich 1955; Boisen 1960). The directive and confrontational model with the focus on nouthetic counselling (Adams 1973) adds to the list, followed by the bipolar model with the dynamics of correlation (Heitink 1999). In this model, Heitink describes the tension between faith and life, theology and psychology. He works from the primary point of departure that a pastoral encounter needs the insight of psychology, for example, but it should preserve the unique input of pastoral theology. After this, scholars such as Josuttis (1982) and Tacke (1996) came to view the purpose of pastoral ministry as life care, where pastoral ministry also includes a social and welfare dimension. It seems as if there has been a diversion from focusing on the individual to a more communal focus over the last few years, which can have a positive effect on the contextualisation of the pastoral ministry in South Africa. Louw (2000) makes the following important remark:

If pastoral theology makes use of a convergence model within which eschatology plays a directive and normative role, then a theological model must employ the formulation: faith care as life care. The object of faith - the dimension of salvation - in reality determines the nature and style of all life care. In the light of a pneumatological perspective in pastoral theology, life care should reveal the relevancy of Christ's incarnation for contextual and existential issues regarding our quest for meaning. (p. 38)

Following this comment, Louw (2000:38) asks the question if there is any scriptural justification for the theory that faith care as life care mediates the gospel's reality and social relevance. Doing pastoral ministry - or then rather faith care as life care - also means becoming aware of and, whenever appropriate, incorporating the different life symbols and metaphors found in scripture into the therapeutic process. The function of symbols and metaphors in the context of pastoral ministry is to connect God's purpose for human existence to real life situations, as it attempts to convey the connection between faith and our lives. Symbols and metaphors evoke strong emotional, psychological and intellectual responses because they are the lenses through which people perceive reality. Louw (2000:39) describes that a metaphor has a referential and transcending character, as it refers to the meaning of an issue and it may even extend the existing field of the issue. Symbols and metaphors also give an individual the opportunity to become integrated into a certain environment, for instance the church, provided that the church and the individual convey the same meaning. In this sense, symbols and metaphors become a binding tool that transcends the individual's existence and existential situation.

According to Mpolo (1985:326), symbols and metaphors are supportive in the creation of a healing community. The challenge for the church is to listen and to reflect on the different cultures' symbols and metaphors theologically in order to incorporate them into pastoral ministry. This forms a connection between unconscious and conscious cognition while bringing into awareness intuitive images that can have a positive effect on communal health, value and life. The use of symbols and metaphors should become part of the process of pastoral ministry, as it is an opportunity to reinvent positive meanings of words and acts. Louw (2000) also states that the discourses on the usage of symbols and metaphors:

$[A]$ lert pastors to the fact that, though they have an interpreting and facilitating function, nevertheless, the secret of care and comfort resides more in the pastors' being functions than in their knowing and doing functions [...]. The various symbols and metaphors serve the useful function of developing sensitivity (the Shepard flock metaphor), conciliation and woundedness (the servant metaphor), discernment and insight (the wisdom metaphor), support and empowerment (the paracletic metaphor). (p. 39)

Apart from the scriptural symbols and metaphors, pastors must be able to recognise symbols when they present themselves to us, for example the hash (\#) symbol that is currently arising in South Africa as a proclamation made by 
the people. Some people are more demonstrative in their spiritual life than others and will continually seek ways to express their needs and feelings. With the use of symbols and metaphors, the pastoral ministry of a church can create the means for intercultural integration and understanding, which can result in communal healing.

\section{Conclusion}

The responsibility of the church is to be on the forefront of creating healthy communities in which all persons can live humane lives and where they are safe, nurtured and empowered to grow. Currently, South Africa is still suffering due to unresolved issues. The cultural diversity has brought new challenges for the church and the pastoral care ministry. This article reflected on the positive effect that the use of symbols and metaphors could have on a better understanding of the different cultures. The article comprises three parts, with the focus first on the culture, world view and religion in the present South Africa; secondly on the understanding of the symbolic process and the usage of symbols and metaphors in pastoral ministry; and lastly on contextual theological thought on the use of symbols and metaphors in pastoral ministry. The aim was to reflect on ways to contribute to the pastoral ministry in articulating effective integration of the different cultures. There is still much to add to this theme, and future articles may add an empirical investigation to this effect.

\section{Acknowledgements Competing interests}

The author declares that she has no financial or personal relationships which may have inappropriately influenced her in writing this article.

\section{References}

Adams, J.E., 1973, Competent to counsel, Presbyterian and Reformed Publishing Company, Grand Rapids.

Bate, S.C., 2012, 'A Theological model of healing to inform an authentic healing ministry', Journal of Theology for Southern Africa 144(1), 69-91.

Boisen, A.T., 1960, Out of the depths: An autobiographical study of mental disorder and religious experience, Harper \& Brothers Publishers, New York.

Bosch, D., 1973, 'God in Africa: Implications for the Kerygma', Miss 1(1), 3-20.

Coll, R., 1985, 'Challenging and reclaiming symbols', Religious Education 80(3), 373-389.

Firet, J., 1980, 'De plaats van de praktische theologie binnen de theologische faculteit', in C.P. van Andel (ed.), Praktische theologie, pp. 10-19, Boekencentrum, The Hague.

Heitink, G., 1999, Practical Theology, WM.B.Eerdmans Publishing Company, Grand Rapids.

Josuttis, M., 1982, Der Pfarrer ist anders: Aspekte einer zeitgenössischen Pastoraltheologie, Kaiser, München.

Kretzschmar, L., 1986, The voice of black theology in South Africa, Ravan Press, Johannesburg.

Lane, B.C., 1987, 'Language, metaphor and pastoral theology', Theology Today 43(4), 487-502.

Lartey, E.Y., 2013, Postcolonializing God: An African Practical Theology, SCM Press, London.

Louw, D.J., 2000, A hermeneutics of pastoral care and encounter, Lux Verbi BM, Cape Town.

Louw, D.J., 2008, Cura Vitae: Illness and healing of life, Lux Verbi BM, Cape Town.

Louw, D.J., 2010, "Care of the human "soul" in contemporary theological formation: From "kerygmatics" to "fortigenetics" in pastoral anthropology', Nederduitse Gereformeerde Teologiese Tydskrif 51(3\&4), 70-81.

Mpolo, M.M.A., 1985, 'African symbols and stories in pastoral care', The Journal of Pastoral Care 39(4), 314-326.

Niebuhr, H.R., 1952, Christ and culture, HarperCollins Publishers, New York.

Oduro, T., Pretorius, H., Nussbaum, S. \& Born, B., 2008, Mission in an African way, Christian Literature Fund, Cape Town.

Osmer, R.A., 2008, Practical theology: An introduction, Eerdmans, Grand Rapids.

Prattis, I., 2001, 'Understanding symbolic process - metaphors, vibration, form', Journal of Ritual Studies 15(1), 38-54.

Tacke, H., 1996, Glaubenshilfe als Lebenshilfe: Probleme und Chancen heutiger Seelsorge, Felix Mucke, Hammelbach.

Tillich, P., 1955, The new being, University of Nebraska Press, Nebraska.

Tutu, D., 1971, 'God - Black or White?' Ministry 11(4), 111.

Van der Walt, B.J., 2003, Understanding and rebuilding Africa, Institute for contemporary Christianity in Africa, Potchefstroom.

Vilanculo, A., 2009, 'African cultural issues and Christian worship - a pastoral perspective', The South African Baptist Journal of Theology 18(1), 234-245. 